\title{
ANALISIS KINERJA PENGELOLAAN KEUANGAN DESA (STUDI PADA KECAMATAN BETUNG KABUPATEN BANYUASIN)
}

\author{
${ }^{1}$ M. Thoyib, ${ }^{2}$ Chandra Satria, ${ }^{3}$ Septiana, ${ }^{4}$ Darul Amri \\ ${ }^{1}$ Politeknik Sriwijaya Palembang. Email: thoyib1958@gmail.com \\ ${ }^{2}$ STEBIS IGM Palembang. Email: chandras@stebisigm.ac.id \\ ${ }^{3}$ Politeknik Sriwijaya Palembang. Email: septiana@gmail.com \\ ${ }^{4}$ Politeknik Sriwijaya Palembang. Email: darulamri@yahoo.co.id
}

\begin{abstract}
The purpose of this study was to determine the performance of village financial management in Betung District, Banyuasin District. Data was collected in this study using a questionnaire, the sample used a purposive sampling method, the research unit was the Village Head, Village Secretariat, Village Treasurer or Head of Finance, Section Chief, Head of Village Affairs and Village Consultative Body. The number of samples in this study (each village 8 respondents with a total of 9 villages), the method of analysis using multiple regression with SPSS version 20 calculations As for the results of the study are the Capacity of Village Apparatuses, Village Financial Reporting Words, BPD Supervision Quality and Village Assistance have a positive and significant effect on the performance of village financial management in Betung District, Banyuasin District, both partially and simultaneously.
\end{abstract}

Keywords: Capacity of Village Apparatus, Reporting Compliance, Quality of Supervision, Village Companion, Management Performance.

\section{DASAR PEMIKIRAN}

Undang-Undang (UU) Nomor 6 Tahun 2014 tentang Desa merupakan bukti komitmen pemerintah Indonesia dalam memperluas sistem desentralisasi sampai dengan elemen pemerintahan terkecil yaitu desa. Pasal 2 dalam UU No. 6 Tahun 2014 menjelaskan bahwa pengaturan desa bertujuan untuk memberikan pengakuan atas desa dengan memberikan kejelasan status dan kepastian hukum menjadi bagian dari sistem Negara Kesatuan Republik Indonesia (NKRI). Selain itu, pengaturan desa juga ditujukan untuk membantu desa dalam mengembangkan aset desa baik dari budaya maupun dari sumber daya manusianya, meningkatkan pelayanan kepada masyarakat dan meningkatkan ketahanan serta perekonomian desa.

Adanya pengaturan desa diharapkan memiliki dampak positif terhadap cakupan yang lebih luas dalam perbaikan pembangunan, ketahanan dan perekonomian nasional. 
14 | M. Thoyib, Chandra Satria, Septiana, Darul Amri Analisis Kinerja Pengelolaan Keuangan Desa.....

Prinsip Nawacita yang dipegang oleh pemerintah menjadi acuan bahwa pembangunan nasional dimulai dari pemerintahan terkecil yaitu desa, sesuai dengan Rencana Pembangunan Jangka Menengah Nasional (RPJMN) Tahun 2015-2019. Pembangunan nasional tidak lagi sepenuhnya berorientasi dari kota melainkan desa yang menjadi garda terdepan dalam keberhasilan dari program pemerintah (Rahayu, 2017).

Jumlah dana yang dikucurkan langsung ke desa dari pemerintah pusat cukup besar, hal tersebut mengakibatkan rawan terjadinya penyelewengan anggaran dari kepentingan pribadi aparatur desa (Husna dan Abdullah, 2016). Selain itu, lemahnya pemahaman aparatur desa dalam pengelolaan keuangan desa mengakibatkan kurang efektif dan efisien kinerja dari pengelolaan keuangan desa (Munti dan Fahlevi, 2017). Menurut Badan Pengawasan Keuangan dan Pembangunan (BPKP) dalam penelitianya Munti dan Fahlevi (2017) menyebutkan bahwa telah ditemukan 15.100 kelemahan yang terjadi dalam akuntabilitas pengelolaan keuangan desa pada tahun 2015. Padahal, tercapainya pembangunan desa yang menjadi tujuan utama dari dana desa sangat ditentukan dari kinerja pengelolaan keuangan oleh aparatur desanya.

Berdasarkan uraian di atas peneliti tertarik dengan tujuan untuk mengetahui faktorfaktor pada penelitian sebelumnya dan penambahan faktor lainnya juga berpengaruh terhadap kinerja pengelolaan keuangan desa di Kecamatan Betung Kabupaten Banyuasin. Oleh karena itu, judul dari penelitian ini adalah "Analisis Kinerja Pengelolaan Keuangan Desa: Studi pada Kecamatan Betung Kabupaten Banyuasin”.

\section{TINJAUAN PUSTAKA}

\section{Pengelolaan Keuangan Desa}

Peraturan Menteri Dalam Negeri Nomor 113 Tahun 2014 tentang Pengelolaan Keuangan Desa, dalam ketentuan umumnya menyebutkan bahwa pengelolaan keuangan desa adalah segala kegiatan yang meliputi perencanaan, pelaksanaan, penatausahaan, pelaporan, dan pertanggungjawaban keuangan desa. Pengelolaan keuangan desa harus berlandaskan pada tiga asas diantaranya akuntabel, transparan, dan partisipatif serta dilakukan dengan tertib dan disiplin anggaran. Pengelolaan keuangan desa dilakukan dalam kurun waktu satu tahun anggaran yang dimulai dari 1 Januari sampai dengan 31 Desember. Kepala desa merupakan pemegang kekuasaan tertinggi terhadap pengelolaan 
keuangan desa, dimana dalam pelaksanaanya dibantu oleh PTPKD (Pelaksana Teknis Pengelola Keuangan Desa). PTPKD terdiri atas sekretaris desa, kepala seksi, dan bendahara desa.

Pengelolaan keuangan desa sesuai dengan Permendagri No. 113 Tahun 2014 menjelaskan bahwa APBDesa terdiri dari pendapatan desa, belanja desa dan pembiayaan desa. Pendapatan desa merupakan semua penerimaan uang melalui rekening desa yang merupakan hak untuk setiap desa dalam satu periode anggaran, pendapatan desa terdiri atas pendapatan asli desa, transfer dari daerah dan pusat serta pendapatan lain-lain. Belanja desa adalah semua pengeluaran yang dilakukan desa melalui rekening desa yang menjadi kewajiban bagi setiap desa dalam jangka waktu satu tahun periode. Pembiayaan desa meliputi semua penerimaan yang perlu dibayarkan kembali dan/atau semua pengeluaran yang akan diterima kembali.

\section{Kinerja Pengelolaan Keuangan Desa}

Sesuai dengan UU No.6 Tahun 2014 tentang Desa Pasal 1 menjelaskan bahwa Desa adalah kesatuan masyarakat hukum yang memiliki batas wilayah tertentu dan berwenang didalamnya dalam menjalankan pemerintahan, kepentingan masyarakat sesuai dengan kesepakatan dari ide masyarakatnya, hak atas asal usul atau tradisional setempat yang diakui dan dihormati dalam sistem pemerintahan NKRI. Untuk mewujudkan tujuan dari sebuah desa tentunya dibutuhkan perwakilan dari desa maupun dari pemerintah daerah yang disebut dengan perangkat atau aparatur desa. Perangkat desa dibutuhkan untuk menjalankan roda pemerintahan desa dimana perangkat desa terdiri dari sekretariat desa, pelaksana kewilayahan, dan pelaksana teknis.

Kinerja pengelolaan keuangan harus sejalan dengan tujuan dari dibentuknya pengaturan desa dalam UU tentang Desa. UU tentang Desa menjelaskan pengaturan desa ditujukan untuk membantu mengembangkan aset desa baik dari budaya maupun dari sumber daya manusianya, meningkatkan pelayanan kepada masyarakat dan meningkatkan ketahanan serta perekonomian desa. Adanya pengaturan desa juga diharapkan memiliki dampak positif terhadap cangkupan yang lebih luas dalam perbaikan pembangunan, ketahanan dan perekonomian nasional. Prinsip Nawacita yang 
16 | M. Thoyib, Chandra Satria, Septiana, Darul Amri Analisis Kinerja Pengelolaan Keuangan Desa..... dipegang oleh pemerintah menjadi acuan bahwa pembangunan nasional dimulai dari pemerintahan terkecil yaitu desa, sesuai dengan RPJMN Tahun 2015-2019.

Didukung dengan Permendagri No. 37 Tahun 2007 tentang Pedoman Pengelolaan Keuangan Desa dijelaskan bahwa desa memiliki hak otonom dimana desa berhak mengurusi keuangan desa sendiri baik pendapatan maupun rancangan pengelolaan aset yang dimiliki dalam pembelanjaan anggaran. Terkait dengan pendapatan desa yang cukup besar pada dua tahun periode terakhir perlu adanya pengukuran kinerja pengelolaan keuangan desa. Mengenai indikator dalam mengukur kinerja Moeheriono (2014) mendefinisikan bahwa indikator kinerja sebagai nilai yang dipergunakan untuk mengukur output atau outcome dari suatu program. Menurut Mardiasmo (2009) dalam bukunya memaparkan beberapa indikator dalam pengukuran kinerja, indikator tersebut diantaranya:

a. Efisiensi, yaitu perbandingan dari input dengan output yang dikaitkan dengan target atau standar kinerja yang sudah ditetapkan.

b. Efektifitas, yaitu perbandingan hasil program dengan target dari program tersebut.

c. Ekonomis, yaitu perbandingan antara input dengan input value yang dinyatakan dalam satuan moneter.

\section{Kapasitas Aparatur Desa}

Kapasitas dapat diartikan sebagai sebuah kemampuan dari manusia, organisasi dan masyarakat dalam mewujudkan kinerja yang baik, untuk mengidentifikasi dan meraih tujuanya, untuk perubahan apabila dibutuhkan dalam usaha keberlangsungan, pengembangan, dan dengan tujuan memajukan (Ubels et al., 2010).

Penyelenggaraan pemerintah desa sebagai garda terdepan dalam pembangunan nasional khusunya dalam urusan pemerintah daerah tentunya memerlukan kapasitas aparatur desa yang memadai (Asrori, 2014). Pemerintahan desa dijalankan oleh perangkat desa, sesuai dengan UU No. 6 Tahun 2014 tentang Desa bahwa perangkat desa terdiri dari sekretariat desa, pelaksana kewilayahan, dan pelaksana teknis yang membantu kepala desa sebagai pimpinan desa dalam mewujudkan tujuan pembangunan desa. 
Kepala desa merupakan perangkat desa yang berperan langsung dalam pengelolaan keuangan desa lebih tepatnya sebagai pemegang kekuasaan atas pengelolaan keuangan desa. Kepala desa dibantu oleh Pelaksana Teknis Pengelolaan Keuangan Desa (PTPKD) dalam melaksanakan pengelolaan keuangan desa, sekretraris sebagai koordinator pelaksanaan pengelolaan keuanagan desa, dan bendahara desa dengan status sebagai staf sekretariatan desa yang bertugas sebagai administrasi keuangan termasuk didalamnya dalam penatausahaan keuangan desa. Terkait dengan pengelolaan keuangan yang baik pada sebuah instansi membutuhkan sumber daya manusia yang berkompeten dengan latar belakang profesional di bidang akuntansi (Rafar et al., 2015).

\section{Ketaatan Pelaporan Keuangan}

Berdasarkan Permendagri No. 113 Tahun 2014 tentang Pengelolaan Keuangan Desa, kepala desa wajib menyampaikan laporan realisasi pelaksanaan APBDesa yang dapat dipertanggungjawabkan kepada bupati/walikota melalui camat paling lambat satu bulan setelah akhir tahun anggaran. Dengan jumlah dana yang tidak sedikit ini tidak menutup kemungkinan akan adanya tindakan penyelewengan yang berkaitan dengan pengelolaan dana desa yang harus dipertanggungjawabkan secara akuntabilitas. Jadi, semakin taat aparut desa terhadap pelaporan keuangan maka semakin bagus pula kinerja pengelolaan keuangan suatu desa tersebut.

Pasal 2 pada Permendagri No. 113 Tahun 2014 tentang Pengelolaan Keuangan Desa memaparkan beberapa asas yang harus dipakai dalam pengelolaan keuangan desa. Asas-asas tersebut diantaranya:

1) Transparan, yaitu keterbukaan terkait informasi mengenai penyelenggaraan pengelolaan keuangan yang berisi kebijakan, rencana, pelaksanaan dan hasil.

2) Akuntabel, yaitu aparatur desa memiliki kemampuan dalam menerangkan dan menjawab kinerja dari pemerintah desa kepada masyarakat.

3) Partisipatif, yaitu proses pengelolaan keuangan desa dari mulai proses perencanaan, pelaksanaan samapai dengan laporan keuangan dan pertanggungjawaban harus mengikutsertakan masyarakat sekaligus mengawasinya. 
18 | M. Thoyib, Chandra Satria, Septiana, Darul Amri Analisis Kinerja Pengelolaan Keuangan Desa.....

4) Tertib dan disiplin, yaitu pengelolaan keuangan desa dilaksanakan dengan tertib dan disiplin sesuai dengan aturan yang berlaku, seperti taat waktu, konsisten, sesuai jumlah.

Permendagri No. 113 Tahun 2014 tentang Pengelolaan Keuangan Desa menjelaskan bahwa kepala desa merupakan pemegang kekuasaan dalam pengelolaan keuangan desa, sekaligus sebagai perwakilan pemerintah desa atas kepemilikan kekayaan milik desa. Kepala desa dibantu oleh sekretaris desa, kepala seksi, dan bendahara selaku PTPKD dalam melaksanakan pengelolaan keuangan desa. Sekretaris desa memiliki tugas sebagai koordinator pelaksana teknis dalam pengelolaan keuangan desa, kepala seksi sebagai pelaksana kegiatan sesuai dengan bidangnya yang ditugaskanya, sedangkan bendahara merupakan staf bagian urusan keuangan.

Laporan keuangan adalah sarana yang digunakan oleh entitas dalam mengkomunikasikan keadaan terkait kondisi dari keuangan entitas tersebut kepada pihak-pihak yang berkepentingan baik dari pihak internal mapun dari pihak eksternal entitas (Kieso et al., 2007). Tujuan dari laporan keuangan adalah memberikan informasi terkait posisi keuangan, kinerja dari keuangan, dan laporan arus kas pada sebuah entitas yang bermanfaat bagi sejumlah besar pengguna laporan keuangan guna pengambilan keputusan ekonomi (Ikatan Akuntansi Indonesia, 2015).

\section{Kualitas Pengawasan Badan Permusyawaratan Desa (BPD)}

Kualitas merupakan segala sesuatu yang dapat memenuhi kebutuhan dan keinginan dari pelanggan (Sinambela dan Poltak, 2010). Pengawasan adalah serangkaian tindakan yang dilakukan oleh manajemen guna mendapatakan informasi apa saja yang sudah dilakukan bawahanya mengenai kesesuaian perintah, rencana, tujuan, dan kebijakan (Simbolon dan Masry, 2004). Pengertian diatas menjelaskan bahwa kualitas dari pengawasan merupakan seberapa banyak kebutuhan informasi yang didapatkan mengenai tujuan dari pengawasan tersebut.

Badan Permusyawaratan Desa di masing-masing desa di wakili oleh minimal lima orang dan maksimal sembilan orang perwakilan, hal tersebut tergantung luas wilayah desa tersebut. BPD dalam sebuah pemerintah desa berperan sebagai legislatif dan aparatur desa sebagai pihak eksekutif dalam lingkup kecil pemerintahan. Sistem 
pemerintahan tersebut yang mengungkapkan bahwa sebuah pemerintahan memerlukan peran eksekutif dan legislatif meskipun dalam lingkup yang terkecil.

\section{Pendamping Desa}

Supervisi yang selanjutnya pendampingan adalah praktik pengarahan, pendampingan, pelatihan dan penilaian yang dilakukan oleh atasan langsung melalui pendelegasian pribadi atau kelompok kepada pribadi atau kelompok pada proses pencapaian target tertentu (Erawati, 2012). Pendamping desa diperlukan oleh sebuah desa terkait dengan UU tentang Desa. Sesuai dengan Peraturan Pemerintah No. 47 Tahun 2015 Pasal 129 ayat 1 menyebutkan bahwa tenaga pendamping desa berasal dari kader pemberdayaan masyarakat desa, pendamping desa dari pemerintah kecamatan, pelaksana teknis yang bekerja di kecamatan sebagai pendamping desa, dan tenaga ahli pemberdayaan masyarakat. Hal ini menjelaskan bahwa pendamping desa bisa berasal dari masyarakat, pemerintah dan bahkan dari pihak swasta.

Tujuan dari pendampingan desa yang termuat dalam Peraturan Menteri Desa (Permendesa) Nomor 3 Tahun 2015 tentang Pendampingan Desa diantaranya:

1) Meningkatkan kapasitas, efektifitas, dan akuntabilitas pemerintah desa dan pembangunan desa.

2) Meningkatkan prakarsa, kesadaran, dan partisipasi masyarakat desa dalam pembangunan desa yang partisipatif.

3) Meningkatkan sinergi program pembangunan desa antar sektor.

4) Mengoptimalkan aset lokal desa secara emansipatoris.

Mengingat tugas dan tanggungjawab dari pendamping desa sangat luas, maka perlu adanya perekrutan pendamping desa yang memiliki kualifikasi mumpuni. Pendamping desa sekurang-kurangnya memiliki kompetensi antara lain (Pasal 4 Permendes PDTT No. 3 Tahun 2015):

1) Mempunyai pengetahun dan kemampuan dalam pemberdayaan masyarakat desa.

2) Memiliki pengalaman dalam berorganisasi yang sejalan dengan pemerintahan desa.

3) Mampu dalam melakukan pendampingan ekonomi masyarakat desa.

4) Mampu memfasilitasi kelompok-kelompok dalam permusyawaratan desa.

5) Memiliki kepekaan terhadap kebiasaan, adat istiadat, dan budaya masyarakat desa. 
20 | M. Thoyib, Chandra Satria, Septiana, Darul Amri Analisis Kinerja Pengelolaan Keuangan Desa.....

Peran dari pendamping desa dalam pemerintahan desa terutama dalam pengelolaan keuanga sangat diperlukan melihat kapasitas aparatur desa yang masih lemah (Prasetyo dan Muis, 2015).

\section{PENELITIAN TERDAHULU}

Beberapa hasil penelitian terdahulu mengenai kinerja pengelolaan keuangan desa dapat dilihat pada tabel berikut.

Tabel 1

\section{Hasil Penelitian Terdahulu}

\begin{tabular}{|c|c|c|c|c|}
\hline No. & Peneliti (Tahun) & Judul Penelitian & Variabel Penelitian & Hasil Penelitian \\
\hline 1 & $\begin{array}{l}\text { Munti dan Fahlevi } \\
\text { (2017) }\end{array}$ & $\begin{array}{l}\text { Determinan Kinerja } \\
\text { Pengelolaan Keuangan } \\
\text { Desa: Studi pada } \\
\text { Kecamatan Gandapura } \\
\text { Kabupaten Bireuen } \\
\text { Aceh }\end{array}$ & $\begin{array}{l}\text { Y: Kinerja } \\
\text { Pengelolaan } \\
\text { Keuangan Desa } \\
\text { X: Kapasitas Aparatur } \\
\text { Desa, Ketaatan } \\
\text { Pelaporan } \\
\text { Keuangan, Kualitas } \\
\text { Pengawasan BPD }\end{array}$ & $\begin{array}{ll}\text { Kapasitas } & \text { Aparatur } \\
\text { Desa, } & \text { Ketaatan } \\
\text { Pelaporan } & \\
\text { Keuangan, } & \\
\text { Kualitas } & \\
\text { Pengawasan } & \\
\text { Berpengaruh } \\
\text { terhadap KPD } \\
\text { Pengelolaan } \\
\text { Keuangan Desa. }\end{array}$ \\
\hline 2 & Jalil (2017) & $\begin{array}{l}\text { Persepsi Perangkat Desa } \\
\text { Terhadap Pengelolaan } \\
\text { Keuangan Desa }\end{array}$ & $\begin{array}{ll}\text { Y: } & \text { Pengelolaan } \\
& \text { Keuangan Desa } \\
\mathrm{X}: & \text { Sumber Daya } \\
& \text { Manusia, } \\
& \text { Informasi, dan } \\
& \text { Partisipasi } \\
& \text { Masyarakat }\end{array}$ & $\begin{array}{l}\text { Sumber Daya } \\
\text { Manusia, Informasi, } \\
\text { dan Partisipasi } \\
\text { Masyarakat } \\
\text { Berpengaruh } \\
\text { Terhadap } \\
\text { Pengelolaan } \\
\text { Keuangan Desa }\end{array}$ \\
\hline 3 & $\begin{array}{l}\text { Prasetyo dan Muis } \\
\text { (2015) }\end{array}$ & $\begin{array}{l}\text { Pengelolaan Keuangan } \\
\text { Desa Pasca UU No. } 6 \\
\text { Tahun 2014 Tentang } \\
\text { Desa: Potensi } \\
\text { Permasalahan dan } \\
\text { Solusi }\end{array}$ & $\begin{array}{l}\text { Y:Keberhasilan } \\
\text { Pengelolaan } \\
\text { Keuangan Desa } \\
\text { X:Kompetensi Kepala } \\
\text { Desa dan } \\
\text { Pendamping Desa }\end{array}$ & $\begin{array}{lr}\text { Kompetensi } & \text { Kepala } \\
\text { Desa } & \text { dan } \\
\text { Pendamping } & \text { Desa } \\
\text { Berpengaruh } & \\
\text { Terhadap } & \\
\text { Pengelolaan } & \\
\text { Keuangan Desa } \\
\end{array}$ \\
\hline 4 & $\begin{array}{l}\text { Mondale dan Fahlevi } \\
\text { (2017) }\end{array}$ & $\begin{array}{l}\text { Analisis Problematika } \\
\text { Pengelolaan Keuangan } \\
\text { Desa }\end{array}$ & $\begin{array}{l}\text { Y:Pengelolaan } \\
\text { Keuangan Desa } \\
\text { X:Kompetensi dan } \\
\text { kualitas SDM, } \\
\text { Partisipasi } \\
\text { Masyarakat, dan } \\
\text { Pengawasan BPD }\end{array}$ & $\begin{array}{lr}\text { Kompetensi dan } \\
\text { kualitas } \\
\text { Partisipasi } \\
\text { masyarakat, dan } \\
\text { pengawasan BPD } \\
\text { menjadi faktor } \\
\text { pendukung dan } \\
\text { penghambat dalam } \\
\text { proses pengelolaan } \\
\text { keuangan Desa }\end{array}$ \\
\hline
\end{tabular}




\begin{tabular}{|c|c|c|c|c|}
\hline 5 & $\begin{array}{l}\text { Dewi, Ramadhanti, } \\
\text { dan Wiratno (2016) }\end{array}$ & $\begin{array}{l}\text { Faktor-faktor yang } \\
\text { Berpengaruh Terhadap } \\
\text { Kinerja Keuangan } \\
\text { Pemerintah Desa Pasca } \\
\text { Penerapan UU No. } 6 \\
\text { Tahun } 2014\end{array}$ & $\begin{array}{l}\text { Y: Kinerja Keuangan } \\
\text { Pemerintah Desa } \\
\text { X:Perencanaan, } \\
\text { Penerapan } \\
\text { Akuntansi Desa, } \\
\text { Penghasilan Tetap, } \\
\text { dan Pengendalian } \\
\text { Internal }\end{array}$ & 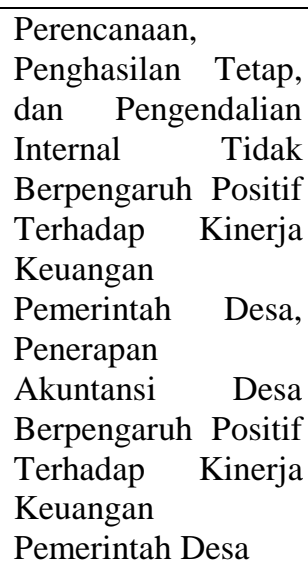 \\
\hline 6 & $\begin{array}{l}\text { Mada, Kalangi, dan } \\
\text { Gamaliel (2017) }\end{array}$ & $\begin{array}{l}\text { Pengaruh Kompetensi } \\
\text { Aparat Pengelola Dana } \\
\text { Desa, Komitmen } \\
\text { Organisasi Pemerintah } \\
\text { Desa, dan Partisipasi } \\
\text { Masyarakat Terhadap } \\
\text { Akuntabilitas } \\
\text { Pengelolaan Dana Desa } \\
\text { di Kabupaten Gorontalo }\end{array}$ & $\begin{array}{l}\text { Y:Akuntabilitas } \\
\text { Pengelolaan Dana } \\
\text { Desa } \\
\text { X: Kompetensi Aparat } \\
\text { Pengelola Dana } \\
\text { Desa, Komitmen } \\
\text { Organisasi } \\
\text { Pemerintah Desa, } \\
\text { dan Partisipasi } \\
\text { Masyarakat. }\end{array}$ & $\begin{array}{l}\text { Kompetensi Aparat } \\
\text { Pengelola Dana } \\
\text { Desa, Komitmen } \\
\text { Organisasi } \\
\text { Pemerintah Desa, } \\
\text { dan Partisipasi } \\
\text { Masyarakat } \\
\text { Berpengaruh Positif } \\
\text { Terhadap } \\
\begin{array}{l}\text { Akuntabilitas } \\
\text { Pengelolaan Dana } \\
\text { Desa }\end{array}\end{array}$ \\
\hline
\end{tabular}

Sumber: data yang diolah 2019

\section{METODE PENELITIAN}

Populasi yaitu seluruh desa di Kecamatan Betung Kabupaten Banyuasin yaitu 9 desa. Pada penelitian ini semua item dalam populasi diambil sebagai sampel. Teknik pengambilan sampel dilakukan melalui metode purposive sampling. Purposive Sampling adalah teknik pengambilan sampel sumber data dengan pertimbangan tertentu. Adapun kriteria sampel yang digunakan dalam penelitian ini adalah Pemerintah Desa yang terlibat langsung dalam kinerja pengelolaan keuangan desa, yang terdiri dari Kepala Desa, Sekretatis Desa, Bendahara Desa/Kaur Keuangan, Kepala Seksi, Kepala Urusan Desa dan Badan Permusyawaratan Desa (BPD). Hal tersebut terdapat pada Peraturan Menteri Dalam Negeri No. 20 Tahun 2018 tentang Pengelolaan Keuangan Desa.

Jumlah sampel dalam penilitian ini ( 8 orang x 9 desa $=72$ orang) yang terdiri dari Kepala Desa serta perangkat desa di Kecamatan Betung sebagai pelaksana pengelolaan keuangan desa. Data yang digunakan dalam penelitian ini adalah data primer yang 
22 | M. Thoyib, Chandra Satria, Septiana, Darul Amri Analisis Kinerja Pengelolaan Keuangan Desa....•

diperoleh melalui penyebar kuesioner yang diberikan kepada semua responden secara langsung. Data pada penelitian ini didapatkan dari penyebaran kuesioner kepada perwakilan dari seluruh sampel desa yang berada di Kecamatan Betung. Sampel desa yang digunakan sebanyak 9 desa dimana kuesioner akan dibagikan di masing-masing desa sebanyak 3-10 kuesioner.

\section{HASIL DAN PEMBAHASAN}

\section{Analisis Regresi Dengan Linier Berganda}

Analisis regresi linear berganda dalam penelitian ini dimaksudkan untuk melihat bagaimana pengaruh Kapasitas Aparatur Desa, Ketaatan Pelaporan Keuangan Desa, Kualitas Pengawasan BPD, dan Pendamping Desa terhadap Kinerja Pengelolaan Keuangan Desa dengan menggunakan bantuan program SPSS 23 didapatkan hasil sebagai berikut:

Tabel 1

Hasil Analisis Regresi Linear Berganda

Coefficients $^{\mathrm{a}}$

\begin{tabular}{|c|c|c|c|c|c|}
\hline \multirow[t]{2}{*}{ Model } & \multicolumn{2}{|c|}{$\begin{array}{c}\text { Unstandardized } \\
\text { Coefficients }\end{array}$} & \multirow{2}{*}{$\begin{array}{c}\text { Standardized } \\
\text { Coefficients } \\
\text { Beta }\end{array}$} & \multirow[t]{2}{*}{$\mathrm{t}$} & \multirow[t]{2}{*}{ Sig. } \\
\hline & $\mathrm{B}$ & Std. Error & & & \\
\hline 1 (Constant) & 3,371 & 1,978 & & 1,704 & ,095 \\
\hline Kapasitas Aparatur Desa & ,212 & 077 & ,295 & 2,754 & ,008 \\
\hline Ketaatan Pelaporan & 270 & רדת & $3 \subset$ & & \\
\hline Keuangan Desa & , 218 & , 077 & ,364 & 3,599 & (001 \\
\hline Kualitas Pengawasan BPD & ,157 & ,067 & 203 & 2,335 & ,024 \\
\hline Pendamping Desa & 174 &, 066 & ,229 & 2,626 & ,011 \\
\hline
\end{tabular}

a. Dependent Variable: Kinerja Pengelolaan Keuangan Desa Sumber: Output SPSS, 2019.

Berdasarkan tabel tersebut, maka diperoleh persamaan regresi linier berganda untuk melihat pengaruh kapasitas aparatur desa, ketaatan pelaporan keuangan, kualitas pengawasan BPD dan pendamping desa terhadap Kinerja pengelolaan keuangan desa pada Kecamatan Betung Kabupaten Banyuasin:

$$
\mathrm{Y}=3,371+0,295 \mathrm{X} 1+0,364 \mathrm{X} 2+0,203 \mathrm{X} 3+0,229 \mathrm{X} 4+\mathrm{e}
$$

Persamaan regresi yang diperoleh dapat dijelaskan sebagai berikut: 
1. Nilai konstanta (a) pada persamaan ini bernilai 3,371 yang menjelaskan bahwa nilai rata-rata kinerja pengelolaan keuangan desa pada kapasitas aparatur desa, ketaatan pelaporan keuangan desa, kualitas pengawasan BPD dan pendamping desa konstan (tidak berubah) atau sama dengan 3,371.

2. Koefisien regresi untuk variabel kapasitas aparatur desa $\left(\mathrm{BX}_{1}\right)$ bertanda positif sebesar 0,295. Artinya bahwa setiap peningkatan kapasitas aparatur desa sebesar 1 (satu) satuan, maka tingkat kinerja pengelolaan kuangan desa akan meningkat sebesar 0,295 dengan asumsi variabel independen lainnya bernilai tetap.

3. Koefisien regresi untuk variabel ketaatan pelaporan keuangan desa $\left(\mathrm{BX}_{2}\right)$ bertanda positif sebesar 0,364. Hal ini berarti bahwa setiap peningkatan SPI sebesar 1 (satu) satuan, maka tingkat kinerja pengelolaan keuangan desa akan meningkat sebesar 0,364 dengan asumsi variabel independen lainnya bernilai tetap.

4. Nilai koefisien regresi untuk variabel kualitas pengawasan BPD (BX3) bertanda positif sebesar 0,203. Artinya, bahwa setiap peningkatan kualitas pengawasan BPD sebesar 1 (satu) satuan, maka tingkat kinerja pengelolaan keuangan desa akan meningkat sebesar 0,203 dengan asumsi variabel independen lainnya bernilai tetap.

5. Nilai koefisien regresi untuk variabel pendamping desa (BX4) bertanda positif sebesar 0,229. Hal ini menunjukkan bahwa setiap peningkatan pendamping desa sebesar 1 (satu) satuan, maka tingkat kinerja pengelolaan keuangan desa akan meningkat sebesar 0,229 dengan asumsi variabel independen lainnya bernilai tetap.

\section{Hasil Uji Hipotesis Regresi Linear Berganda}

\section{a. Hasil Uji Signifikansi Parsial (uji t)}

Uji t atau uji koefisien regresi secara parsial digunakan untuk mengetahui apakah secara parsial variabel independen berpengaruh secara signifikan atau tidak terhadap variabel dependen. Hasil uji t dalam penelitian ini dapat dilihat pada tabel 4.11 berikut ini: 
24 | M. Thoyib, Chandra Satria, Septiana, Darul Amri Analisis Kinerja Pengelolaan Keuangan Desa.....

Tabel 2

Hasil Uji Parsial (uji t)

Coefficients $^{\mathrm{a}}$

\begin{tabular}{|l|r|r|r|r|r|}
\hline \multirow{2}{*}{ Model } & \multicolumn{2}{|c|}{$\begin{array}{c}\text { Unstandardized } \\
\text { Coefficients }\end{array}$} & $\begin{array}{c}\text { Standardized } \\
\text { Coefficients }\end{array}$ & \multirow{2}{*}{$\mathrm{t}$} & Sig. \\
\cline { 2 - 5 } & \multicolumn{1}{|c|}{$\mathrm{B}$} & Std. Error & \multicolumn{1}{c|}{ Beta } & \\
\hline 1 (Constant) & 3,371 & 1,978 & & 1,704 &, 095 \\
Kapasitas Aparatur Desa &, 212 &, 077 &, 295 & 2,754 &, 008 \\
Ketaatan Pelaporan &, 278 &, 077 &, 364 & 3,599 &, 001 \\
Keuangan Desa &, 157 &, 067 &, 203 & 2,335 &, 024 \\
Kualitas Pengawasan BPD &, 174 &, 066 &, 229 & 2,626 &, 011 \\
\hline
\end{tabular}

a. Dependent Variable: Kinerja Pengelolaan Keuangan Desa

Sumber: Output SPSS, 2019.

Berdasarkan tabel tersebut di atas, dapat dilihat bahwa nilai signifikansi untuk variabel kapasitas aparatur desa sebesar 0,008 dan bernilai lebih kecil dari 0,05, maka dapat disimpulkan bahwa variabel Penerapan SAP kapasitas aparatur desa secara parsial berpengaruh positif dan signifikan terhadap Kinerja pengelolaan keuangan desa. Nilai signifikansi variabel ketaatan pelaporan keuangan desa sebesar 0,001 dan bernilai lebih kecil dari 0,05, maka dapat disimpulkan bahwa variabel ketaatan pelaporan keuangan desa secara parsial berpengaruh positif dan signifikan terhadap Kinerja pengelolaan keuangan desa. Sementara itu, nilai signifikansi untuk variabel kualitas pengawasan BPD sebesar 0,024 dan bernilai lebih kecil dari 0,05, jadi dapat disimpulkan bahwa variabel kualitas pengawasan BPD secara parsial berpengaruh positif dan signifikan terhadap Kinerja pengelolaan keuangan desa. Sedangkan variabel pendamping desa memiliki nilai signifikansi sebesar 0,011 atau lebih kecil dari 0,05 sehingga dapat disimpulkan bahwa variabel pendamping desa berpengaruh positif dan signifikan terhadap Kinerja pengelolaan keuangan desa secara parsial.

Berdasarkan hasil analisis di atas, dapat diketahui bahwa nilai $t_{\text {hitung }}$ untuk variabel kapasitas aparatur desa adalah sebesar 2,574dengan nilai $\mathrm{t}_{\text {tabel }}$ pada tingkat signifikan $5 \%$ dan derajat bebas n-k-1 = 54-4-1 = 50 sebesar 2,008. Jika nilai t ini dibandingkan, maka nilai $t_{\text {hitung }}$ masih lebih besar dibandingkan dengan $t_{\text {tabel. }}$. Hal ini dapat dinyatakan bahwa ada hubungan positif dan signifikan antara kapasitas aparatur desa dengan kinerja pengelolaan keuangan desa yang berarti bahwa Ho ditolak dan Ha diterima. Variabel Ketaatan pelaporan keuangan desa nilai $t_{\text {hitung }}$ sebesar 3,599 dengan nilai $t_{\text {tabel }}$ pada 
tingkat signifikan 5\% dan derajat bebas $\mathrm{n}-\mathrm{k}-1=55-4-1=50$ sebesar 2,008. Jika nilai $\mathrm{t}$ ini dibandingkan maka nilai $t_{\text {hitung }}$ lebih besar dibandingkan dengan $t_{\text {tabel }}$ sehingga dapat dinyatakan bahwa ada hubungan positif dan signifikan antara ketaatan pelaporan keuangan desa dengan kinerja pengelolaan keuangan desa yang berarti bahwa Ho ditolak dan Ha diterima.

Sementara itu, nilai $t_{\text {hitung }}$ untuk variabel kualitas pengawasan BPD adalah sebesar 2,335 dengan nilai $\mathrm{t}_{\text {tabel }}$ pada tingkat signifikan 5\% dan derajat bebas $\mathrm{n}-\mathrm{k}-1=55-4-1=$ 50 sebesar 2,008. Jika nilai $\mathrm{t}$ ini dibandingkan maka nilai thitung masih lebih besar dibandingkan dengan $t_{\text {tabel }}$ dengan kata lain dapat dinyatakan bahwa ada hubungan positif dan signifikan antara kualitas pengawasan BPD dengan kinerja pengelolaan keuangan desa yang berarti bahwa Ho ditolak dan Ha diterima. Selain itu, nilai $t_{\text {hitung }}$ untuk variabel pendamping desa adalah sebesar 2,626 dengan nilai $t_{\text {tabel }}$ pada tingkat signifikan $5 \%$ dan derajat bebas $\mathrm{n}-\mathrm{k}-1=55-4-1=50$ sebesar 2,008. Jika nilai $\mathrm{t}$ ini dibandingkan maka nilai thitung masih lebih besar dibandingkan dengan $t_{\text {tabel }}$ sehingga dapat dinyatakan bahwa ada hubungan positif dan signifikan antara pendamping desa dengan kinerja pengelolaan keuangan desa yang berarti bahwa Ho ditolak dan Ha diterima.

\section{b. Hasil Uji Signifikansi Simultan (uji F)}

Uji $F$ atau uji koefisien regresi secara bersama-sama digunakan untuk mengetahui apakah secara bersama-sama variabel independen berpengaruh signifikan terhadap variabel dependen. Hasil uji F dapat dilihat dalam tabel berikut:

\section{Tabel 3 Hasil Uji Simultan (uji F)}

ANOVA $^{\mathrm{a}}$

\begin{tabular}{|ll|r|r|r|r|r|}
\hline Model & & Sum of Squares & Df & Mean Square & F & \multicolumn{1}{c|}{ Sig. } \\
\hline 1 & Regression & 151,576 & 4 & 37,894 & 33,974 &, $000^{\mathrm{b}}$ \\
& Residual & 55,769 & 50 & 1,115 & & \\
& Total & 207,345 & 54 & & & \\
\hline
\end{tabular}

a. Dependent Variable: Kinerja Pengelolaan Keuangan Desa 
26 | M. Thoyib, Chandra Satria, Septiana, Darul Amri Analisis Kinerja Pengelolaan Keuangan Desa....•

b. Predictors: (Constant), Pendamping Desa, Kualitas Pengawasan BPD, Ketaatan Pelaporan Keuangan Desa, Kapasitas Aparatur Desa

Sumber: Output SPSS, 2019.

Berdasarkan tabel di atas, dapat dilihat nilai $\mathrm{F}$ sebesar 33,974 dengan taraf signifikansi 0,000. Hal ini berarti bahwa secara simultan kapasitas aparatur desa, ketaatan pelaporan keuangan desa, kualitas pengawasan BPD dan pendamping desa berpengaruh positif dan signifikan terhadap kinerja pengelolaan keuangan desa.

\section{c. Hasil Uji Koefisien Determinasi}

Koefisien Determinasi $\left(\mathrm{R}^{2}\right)$ digunakan untuk mengukur seberapa jauh kemampuan model dalam menerangkan variasi variabel dependen. Nilai koefisiens determinasi adalah nol dan satu. Nilai $\mathrm{R}^{2}$ yang kecil berarti kemampuan variabelvariabel independen memberikan hampir semua informasi yang dibutuhkan untuk memprediksi variasi variabel dependen. Berikut hasil pengujian koefisien determinasi pada tabel berikut:

\section{Tabel 4}

\section{Hasil Uji Koefisien Determinasi}

\begin{tabular}{|c|c|c|c|c|}
\hline \multicolumn{5}{|c|}{ Model Summary } \\
\hline Model & $\mathrm{R}$ & R Square & Adjusted R Square & $\begin{array}{c}\text { Std. Error of the } \\
\text { Estimate }\end{array}$ \\
\hline 1 &, $855^{a}$ & ,731 & ,710 & 1,056 \\
\hline
\end{tabular}

a. Predictors: (Constant), Pendamping Desa, Kualitas Pengawasan BPD, Ketaatan Pelaporan Keuangan Desa, Kapasitas Aparatur Desa

b. Dependent Variable: Kinerja Pengelolaan Keuangan Desa Sumber: Output SPSS, 2019.

Berdasarkan tabel di atas, dapat dilihat bahwa hasil pengujian regresi berganda diperoleh koefisien determinasinya $\left(\mathrm{R}^{2}\right)$ sebesar $73,1 \%$. Sedangkan $26,9 \%$ sisanya merupakan variabel lain yang tidak termasuk dalam penelitian ini.

\section{KESIMPULAN}

Berdasarkan hasil analisis data dan pengujian hipotesis yang telah diuraikan pada bab sebelumnya, maka penulis mengambil kesimpulan mengenai Pengaruh Kapasitas Aparatur Desa, Ketaatan Pelaporan Keuangan Desa, Kualitas Pengawasan Badan 
Permusyawaratan Desa dan Pendamping Desa terhadap Kinerja Pengelolaan Keuangan

Desa sebagai berikut:

1. Kapasitas Aparatur Desa (X1), Kataatan Pelaporan Keuangan Desa (X2), Kualitas Pengawasan BPD (X3) dan Pendamping Desa (X4) berpengaruh positif dan signifikan terhadap kinerja pengelolaan keuangan desa di Kecamatan Betung Kabupaten Banyuasin secara parsial. Hal ini menunjukkan bahwa semakin tinggi kapasitas aparatur desa, ketaatan dalam pelaporan keuangan desa, semakin tinggi kualitas pengawasan BPD dan sangat berperannya pendamping desa maka kinerja pengelolaan keuangan desa di Kecamatan Betung Kabupaten Banyuasin juga akan meningkat menjadi lebih baik.

2. Kapasitas Aparatur Desa (X1), Kataatan Pelaporan Keuangan Desa (X2), Kualitas Pengawasan BPD (X3) dan Pendamping Desa (X4) berpengaruh positif dan signifikan terhadap kinerja pengelolaan keuangan desa di Kecamatan Betung Kabupaten Banyuasin secara Simultan.

3. Kapasitas Aparatur Desa (X1), Kataatan Pelaporan Keuangan Desa (X2), Kualitas Pengawasan BPD (X3) dan Pendamping Desa (X4) dapat memberikan hampir semua informasi mengenai kinerja pengelolaan keuangan desa di Kecamatan Betung Kabupaten Banyuasin. Hal ini ditunjukkan dari nilai $\mathrm{R}^{2}$ yakni 0, 731 yang menunukkan bahwa setiap variabel independen (X1-X4) memberikan kontribusi sebesar $73,1 \%$ dan sisanya yakni sebesar 26,9\% yang tidak termasuk dalam penelitian ini.

4. Variabel independen yang memiliki pengaruh terbesar terhadap variabel dependen yakni variabel X2 berupa Ketaatan Pelaporan Keuangan Desa yang memiliki nilai 0,364 atau sebesar $36,4 \%$.

\section{DAFTAR PUSTAKA}

Asrori. (2014). "Kapasitas Perangkat Desa dalam Penyelenggaraan Pemerintahan Desa di Kabupaten Kudus". Jurnal Bina Praja, 6(2), 101-116.

Astuti Dewi, R., Ramadhanti, W., \& Wiratno, A. (2016). "Faktor-faktor yang Berpengaruh Terhadap Kinerja Keuangan Pemerintah Desa Pasca Penerapan 
28 | M. Thoyib, Chandra Satria, Septiana, Darul Amri Analisis Kinerja Pengelolaan Keuangan Desa....•

Undang-Undang Nomor 6 Tahun 2014". Jurnal Akuntansi Aktual, 3(4), 311327.

Departemen Keuangan Republik Indonesia. (2017). Rincian Dana Desa Tahun Anggaran 2017 Menurut Kabupaten/ Kota.

Fitriana, D. (2015). "Pengaruh Sumber Daya Manusia, Informasi Keuangan Desa, Komitmen Organisasi Terhadap Kinerja Kepala Desa Dengan Pengelolaan Keuangan Desa Sebagai Variabel Intervening". Skripsi. Universitas Airlangga.

Hanafi Adha, A. (2016). "Pengaruh Pengawasan Badan Permusyawaratan Desa (BPD) Terhadap Kinerja Kepala Desa dalam Pembangunan Desa Rambah Utama Kecamatan Rambah Samo Kabupaten Rokan Hulu". Jurnal Online Mahasiswa, $3(2), 1-15$.

Jalil, Arifin M. 2017. "Persepsi Perangkat Desa Terhadap Pengelolaan Keuangan Desa (Studi Kasus dan Perbandingan Pengelolaan Keuangan di Desa Ngargomulyo, Desa Keningar, dan Desa Dukun Kecamatan Dukun Kabupaten Magelang Tahun 2016-2017)". Skripsi. Universitas Muhammadiyah Yogyakarta.

Ikatan Akuntansi Indonesia. (2015). Standar Akuntansi Keuangan. Jakarta: Salemba Empat.

Islami, U. (2016). "Kapasitas Aparatur Desa dalam Tertib Administrasi Desa (Studi Kasus di Desa Tiuh Tohou Kecamatan Menggala Kabupaten Tulang Bawang)". Skripsi. Universitas Lampung.

Kieso, E. D, dkk. (2007). Akuntansi Intermediate (Kesepuluh). Jakarta: Erlangga

Mada, S., Kalangi, L., \& Gamaliel, H. (2017). "Pengaruh Kompetensi Aparat Pengelola Dana Desa , Komitmen Organisasi Pemerintah Desa, dan Partisipasi Masyarakat Terhadap Akuntabilitas Pengelolaan Dana Desa Di Kabupaten Gorontalo". Jurnal Riset Akuntansi dan Auditing, Vol 8, No, 106-115.

Mardiasmo. (2009). Akuntansi Sektor Publik. Yogyakarta: Penerbit ANDI.

Moeheriono. (2012). Perencanaan, Aplikasi \& Pengembangan Indikator Kinerja Utama Bisnis dan Publik. Jakarta: Rajawali Pers.

Moeheriono. (2014). Pengukuran Kinerja Berbasis Kompetensi. Jakarta: Rajawali Pers.

Mondale, T. F., Fahlevi, H., \& Aliaman. (2017). "Analisis Problematika Pengelolaan Keuangan Desa ( Studi Perbandingan pada Desa Blang Kolak I dan Desa Blang Kolak II , Kabupaten Aceh Tengah)". Jurnal Perspektif Ekonomi Darussalam, 3(2), 196-212.

Munti, F., \& Fahlevi, H. (2017). "Determinan Kinerja Pengelolaan Keuangan Desa: Studi pada Kecamatan Gandapura Kabupaten Bireuen Aceh". Jurnal Akuntansi dan Investasi, 18(2), 172-182.

Nasir, A., \& Oktari, R. (2011). "Pengaruh Pemanfaatan Teknologi Informasi Dan Pengendalian Intern Terhadap Kinerja Instansi Pemerintah (Studi Pada Satuan Kerja Perangkat Daerah Kabupaten Kampar)". Jurnal Ekonomi, 19(2). 
Nazaruddin, I., \& Tri Basuki, A. (2015). Analisis Statistik dengan SPSS. Yogyakarta: Danisa Media.

Nurmiati. (2017). "Efek Moderasi Good Governance Meningkatkan Kinerja Pengelolaan Keuangan Daerah Kabupaten Pangkep". Jurnal Ekonomi, Manajemen, dan Akuntansi, 7(2), 230-244.

Nurzianti, R., \& Anita. (2014). "Pengaruh Karakteristik Tujuan Anggaran Terhadap Kinerja Aparat Pemerintah Daerah Di Kabupaten Aceh Besar". Jurnal Dinamika Akuntansi dan Bisinis, 1(1), 58-71.

Pahlevi, R. (2017). "Kewenangan Pendamping Desa dalam Rangka Penyelenggaraan Pemerintah Desa (Studi Di Desa Pugung Raharjo Kabupaten Lampung Timur)". Jurnal Ilmiah Hukum Administrasi Negara, 4(2).

Parwati, Juni K, dkk. (2017). "Pengaruh Kompetensi Pendamping Desa, Sistem Pengendalian Internal Pemerintah Desa, Dan Komitmen Aparatur Desa Terhadap Keberhasilan Pengelolaan Dana Desa di Kabupaten Buleleng". Jurnal Ilmiah Mahasiswa Akuntansi, 8(2).

Peraturan Pemerintah No. 47 Tahun 2015.

Permendagri No. 113 Tahun 2014 Tentang Pengelolaan Keuangan Desa.

Permendagri No. 37 Tahun 2007 Tentang Pedoman Pengelolaan Keuangan Desa.

Permendesa No. 3 Tahun 2015 Tentang Pendampingan Desa.

Prasetyo, A. G., Muis, A., \& Negara, L. A. (2015). Pengelolaan Keuangan Desa Pasca UU No. 6 Tahun 2014 Tentang Desa: Potensi Permasalahan Dan Solusi. Jurnal Desentralisasi, 13(1), 16-31.

Rafar, T. M., Fahlevi, H., \& Basri, H. (2015). "Pengelolaan Keuangan Daerah （Studi pada Satuan Kerja Perangkat Daerah Pemerintah Kabupaten Aceh Utara)". Jurnal Magister Akuntansi Pascasarjana Universitas Syiah Kuala, 4(2), 64-71.

Rahayu, D. (2017). "Strategi Pengelolaan Dana Desa untuk Meningkatkan Kesejahteraan Masyarakat". Economics Development Analisis Journal, 6(2), 107-116.

Santoso, Hendry. (2018). "Determinan Kinerja Pengelolaan Keuangan Desa (Studi pada Kecamatan Wadaslintang Kabupaten Wonosobo)". Skripsi.Universitas Muhammadiyah Yogyakarta: Fakultas Ekonomi dan Bisnis.

Simbolon, \& Masry, M. (2004). Dasar-dasar Administrasi dan Manajemen. Jakarta: Ghalia Indonesia.

Sinambela, \& Poltak, L. (2010). Reformasi Pelayanan Publik. Jakarta: PT. Bumi Aksara.

Subarsono. (2005). Analisis Kebijakan Publik. Yogyakarta: Pustaka Pelajar.

Sugiarti, E., \& Yudianto, I. (2017). "Analisis Faktor Kompetensi Sumber Daya Manusia , Pemanfaatan Teknologi Informasi, dan Partisipasi Penganggaran Terhadap Akuntabilitas Pengelolaan Dana Desa ( Survei Pada Desa-Desa di Wilayah 
30 | M. Thoyib, Chandra Satria, Septiana, Darul Amri Analisis Kinerja Pengelolaan Keuangan Desa.....

Kecamatan Klari, Kecamatan Karawang Timur, Kecamatan Majalaya". Skripsi. Universitas Widyatama.

Sugiyono. (2014). Metode Penelitian Bisnis: Pendekatan Kuantitatif, Kualitatif dan $R \& D$. Bandung: Penerbit Alfabeta.

Susanti, R. (2015). "Efektivitas Pendampingan Desa dan Partisipasi Masyarakat dalam Pembangunan Infrastruktur Pedesaan Di Desa Sekodi Kecamatan Bengkalis Kabupaten Bengkalis". Jurnal Online Mahasiswa, 2(1), 1-15.

Undang-Undang No.6 Tahun 2014 Tentang Desa. 